\title{
BENTUK TANGGUNG JAWAB NEGARA DALAM PENYEDIAAN BUKU BACAAN KE PULAU-PULAU KECIL TERLUAR
}

\author{
Sunardi Purwanda ${ }^{1}$ dan Muh. Akbar Fhad Syahril ${ }^{2}$ \\ Prodi Ilmu Hukum, Sekolah Tinggi Ilmu Hukum (STIH) Amsir ${ }^{1}$ \\ Prodi Ilmu Hukum, Sekolah Tinggi Ilmu Hukum (STIH) Amsir ${ }^{2}$ \\ Email: sunardipurwandaa@gmail.com \\ Email : akbar9.a9@gmail.com
}

\begin{abstract}
This research aims to know the form of state responsibility through the equalization of reading books to the outer small islands. In terms of dictating the extent of Indonesia's territory to the outer small islands, which are far from the central or central government, the country must take development policies that prioritize areas that fall into the category of less developed and are far from the center of government which in this case is the outermost small islands. This is solely to create equality and eliminate the knowledge gap that all aim to educate the nation's life.
\end{abstract}

Keywords: Responsibility; Country; Reading Books; and The Outer Small Islands.

\begin{abstract}
Abstrak
Penelitian ini bertujuan mengetahui bentuk tanggung jawab negara melalui pemerataan buku bacaan ke pulau-pulau kecil terluar. Dalam hal mentaktisi luasnya wilayah Indonesia hingga ke daerah pulau-pulau kecil terluar, yang berjauhan dengan wilayah pusat atau pemerintah pusat, maka negara mesti mengambil kebijakan pembangunan yang memprioritaskan daerah-daerah yang masuk dalam kategori kurang berkembang dan berada jauh dari pusat pemerintahan yang dalam hal ini adalah daerah pulau-pulau kecil terluar. Hal ini semata-mata untuk menciptakan kesetaraan dan memupus kesenjangan pengetahuan yang semuanya bertujuan mencerdaskan kehidupan bangsa.
\end{abstract}

Kata Kunci: Tanggung Jawab; Negara; Buku Bacaan; dan Pulau-pulau Kecil Terluar.

\section{PENDAHULUAN}

Mencerdaskan kehidupan bangsa merupakan satu dari empat tujuan negara dalam pembukaan Undang-Undang Dasar 1945. Dalam mencapai tujuan negara tersebut, diaturlah dalam Pasal 31 ayat (1) UUD 1945, bahwa setiap warga negara berhak mendapatkan pendidikan. 
Guna memenuhi tujuan negara tersebut, maka diselenggarakanlah pendidikan yang bermutu, mulai tingkat dasar, menengah hingga tingkat perguruan tinggi. ${ }^{1}$ Bahkan Negara Indonesia mewajibkan, anak-anak harus bersekolah selama sembilan tahun. ${ }^{2}$

Selain mewajibkan anak-anak untuk mengikuti pendidikan dasar di sekolah, negara juga serius membenahi urusan pendukung pendidikan, seperti urusan budaya membaca dan ketersediaan buku bacaan. Keseriusan ini dapat kita temukan dari prinsip-prinsip pendidikan yang telah menjadi acuan negara dalam proses penyelenggaraan pendidikan. Dari sekian prinsip, di antaranya menetapkan ${ }^{3}$ pendidikan mesti diselenggarakan dengan mengembangkan budaya membaca bagi segenap warga negara. Selain itu, keseriusan ini juga dapat kita lihat dari peran negara dalam membentuk lembaga pusat perbukuan yang bertugas menyediakan dan mendistribusikan buku-buku bacaan.

Adanya keinginan dari negara terhadap pengembangan budaya membaca dan ketersediaan buku bacaan bagi segenap warga masyarakat, telah dituangkan dalam Undang-undang Nomor 3 Tahun 2017 tentang Sistem Perbukuan (UU Sisbuk). Dalam konsideran menimbang huruf (b) UU Sisbuk tertulis bahwa buku sebagai salah satu sarana membangun dan meningkatkan budaya literasi ${ }^{4}$ masyarakat Indonesia agar masyarakat berperan dalam tingkat global. Dalam Pasal 8 dan 10 UU Sisbuk menetapkan bahwa ada hak-hak untuk masyarakat dalam bidang perbukuan. Pasal 8 UU Sisbuk memberikan hak kepada masyarakat (umum) untuk mendapatkan kemudahan akses terhadap buku bermutu. Rumusan yang lebih khusus nampak dalam Pasal 10 UU Sisbuk yang menetapkan, masyarakat di daerah terdepan, terluar, tertinggal, komunitas adat terpencil, serta

\footnotetext{
${ }^{1}$ Pasal 14 Undang-undang No. 20 Tahun 2003 tentang Sistem Pendidikan Nasional.

2 Pasal 6 (1) Undang-undang No. 20 Tahun 2003 tentang Sistem Pendidikan Nasional.

${ }^{3}$ Pasal 4 Undang-undang No. 20 Tahun 2003 tentang Sistem Pendidikan Nasional.

4 Membaca sebenarnya merupakan bentuk kebudayaan (budaya literasi). Oleh karena itu untuk mengubah masyarakat yang enggan membaca menjadi masyarakat baca (reading society) diperlukan adanya perubahan budaya. Lihat Tilaar dalam Triningsih. 2019. Perpustakaan dan Budaya Baca Tulis. Yogyakarta: Azyan Mitra Media, hlm. 1.
} 
yang mengalami bencana berhak memperoleh layanan akses buku. Selain ditentukan dalam UU Sisbuk, UU No. 43 Tahun 2007 tentang Perpustakaan (UU Perpustakaan) juga memiliki korelasi dalam urusan pemenuhan hak atas buku bacaan. Dalam Pasal 5 UU Perpustakaan, telah ditetapkan bahwa masyarakat mempunyai hak yang sama untuk memperoleh layanan serta memanfaatkan dan mendayagunakan fasilitas perpustakaan..., dan masyarakat di daerah terpencil, terisolasi, atau terbelakang sebagai akibat faktor geografis berhak memperoleh layanan perpustakaan secara khusus.

Hadirnya hak, tentu pula melahirkan kewajiban dan tanggung jawab pemerintah. Dalam Pasal 36 (a) dan 39 (a) UU Sisbuk, pemerintah pusat dan daerah menjamin tersedianya buku bermutu, murah, dan merata tanpa diskriminasi. Selain kewajiban tersebut, tanggung jawab pemerintah pusat dan daerah juga dapat dilihat dalam Pasal 36, 39, dan 41 UU Sisbuk, sedangkan untuk kewajiban pemerintah dalam urusan perpustakaan dapat dilihat dalam Pasal 7 dan 8 UU Perpustakaan.

Hanya saja, keseriusan negara dalam mengatur aspek pendidikan tidak sesuai dengan apa yang kemudian terjadi di lapangan. Prinsip "budaya membaca" tersebut tidak searah dengan apa yang diinginkan oleh negara melalui regulasi soal pendidikan. Budaya membaca warga negara kita rendah, sesuai apa yang dihasilkan oleh beberapa riset yang menunjukkan bahwa warga negara lemah dalam urusan ini. Data statistik yang dirilis oleh United Nations Educational, Scientific and Cultural Organization (UNESCO) pada tahun 2016, menunjukkan indeks 0,001\%, yang berarti 1.000 orang Indonesia, ada satu orang yang memiliki kegemaran membaca. Kemudian pada tahun yang sama, sebuah rilis dikeluarkan Central Connecticut State University, memublikasikan tingkat melek baca masyarakat terhadap 61 negara dan mendudukkan Indonesia pada peringkat 60 . Namun, apakah betul warga negara Indonesia memang lemah dalam urusan 
membaca, ataukah ketidaktersediaan akses buku bacaan ${ }^{5}$ yang kurang memadai sehingga warga negara lemah dalam urusan membaca.

Begitupun dalam hal persoalan distribusi buku bacaan. Masalah pengiriman buku bacaan merupakan persoalan di sebuah negara kepulauan terbesar seperti Indonesia. ${ }^{6}$ Dengan lebih dari 17.000 pulau dan memiliki 10 wilayah perbatasan maritim dengan negara tetangga, barang tentu membutuhkan anggaran yang besar dalam pemenuhan hak-hak warga negara. Kebijakan pembangunan aspek pendidikan sebagai bentuk tanggung jawab negara dengan menyediakan akses terhadap buku bacaan akan mengalami kendala apabila tidak disokong oleh anggaran yang besar dan regulasi yang disusun secara matang dan terencana. Apabila mengacu pada Keppres RI No. 6 Tahun 2017, terdapat 111 pulau kecil terluar yang berhadapan langsung dengan negara tetangga. Kondisi tersebut, bagaimanapun juga, sangat rentan terhadap kondisi geo-politik, baik dari dalam maupun luar negeri. Lalu, langkah apakah yang mesti dilakukan oleh pemerintah dalam hal penyediaan buku-buku bacaan ke wilayah pulau-pulau kecil terluar? Langkah ini nantinya diharapkan mampu meminimalisir segala bentuk tindakan yang merugikan ketahanan nasional, dan sebagai upaya memupus kesenjangan pengetahuan.

\section{PEMBAHASAN}

Gerakan yang gencar dibangun saat ini, tidak lebih dari upaya membumikan urusan literasi di tengah-tengah masyarakat. Di Indonesia, gerakan ini merupakan bagian dari apa yang dikenal saat ini dengan sebutan "budaya literasi”. Budaya literasi bertujuan, salah satunya, membumikan

${ }^{5}$ Para pegiat literasi yang tergabung dalam Pustaka Bergerak Indonesia menemukan fakta yang berbeda, yang berasumsi bahwa, sejauh ini bukan karena masyarakat Indonesia tidak gemar membaca, hanya saja akses terhadap layanan buku bacaan yang kurang, sehingga minat baca menjadi rendah. Lihat Nirwan Ahmad Arsuka. 2008. Semesta Manusia. Yogyakarta: Ombak, hlm. 728 \& 733.

${ }^{6}$ Lihat di https://www.republika.co.id/berita/pendidikan/eduaction/17/10/27/oyhf2h382-kemendikbud-akui-sulitmenghadirkan-buku-ke-daerah-3t 
buku-buku bacaan dan mendekatkan pengetahuan di tengah-tengah masyarakat. Mengapa buku, dan bukan yang lain? Itu karena buku merupakan fenomena kebudayaan. ${ }^{7}$

Dalam pengembangan budaya literasi, negara bertanggung jawab memenuhi hak-hak warga negaranya, terutama dalam memperoleh layanan akses buku bacaan. ${ }^{8}$ Namun, dalam kenyataannya pemerataan buku belum terealisasi secara utuh. Buku hanya berkutat di kota-kota besar, ditandai dengan hadirnya berbagai perpustakaan, baik yang berbayar maupun yang model pinjam-meminjam, dan hal ini belum berlangsung secara merata ke daerah pulau-pulau kecil terluar. Padahal Undang-Undang No. 3 Tahun 2017 tentang Sistem Perbukuan telah mengatur sedemikian rupa agar terwujud sistem perbukuan secara adil dan merata. ${ }^{9}$ Bahkan, pemerintah pusat dan daerah menjamin tersedianya buku bermutu, murah, dan merata tanpa diskriminasi. ${ }^{10}$

Selain memunculkan diskriminasi, juga mengingkari prinsip-prinsip hak dalam Hak Asasi Manusia (HAM) yang interrelated, interdependent, dan indivisible. Pengingkaran prinsip HAM ini menutup kesempatan sosial dalam bentuk penyediaan fasilitas pendidikan dapat memfasilitasi partisipasi ekonomi yang dapat mendorong kemakmuran dan pengayaan sumber-sumber publik untuk fasilitas sosial. ${ }^{11}$ Hal mana tentu tidak sejalan dengan konsideran menimbang huruf (b) dan Pasal 4 huruf (c) UU No. 3 Tahun 2017 tentang Sistem Perbukuan, bahwa buku sebagai salah satu sarana membangun dan meningkatkan budaya literasi masyarakat Indonesia perlu mendapatkan perhatian khusus guna mendorong masyarakat berperan dalam tingkat global.

Asumsi dari pegiat literasi yang menganggap bahwa sejauh ini bukan karena masyarakat Indonesia tidak gemar membaca, tetapi akses terhadap layanan buku bacaan yang kurang, telah

\footnotetext{
${ }^{7}$ Ignas Kleden dalam Alfons Taryadi (ed.). 1999. Buku dalam Indonesia Baru. Jakarta: Yayasan Obor Indonesia dan The Japan Foundation, hlm. 48.

8 .Lihat pasal 10 UU No. 3 Tahun 2017 tentang Sistem Perbukuan.

${ }^{9}$ Lihat pasal 4 huruf (b) UU No. 3 Tahun 2017 tentang Sistem Perbukuan.

${ }^{10}$ Lihat Pasal 36 huruf (a) dan 39 huruf (a) UU No. 3 Tahun 2017 tentang Sistem Perbukuan.

${ }^{11}$ Amartya Sen. 1999. Development as Freedom. New York: Alfred A. Knopf, hlm. 10-24.
} 
dibuktikan oleh hasil penelitian disertasi dari Sunardi Purwanda yang terkait pemenuhan hak atas bacaan bagi masyarakat di Daerah Terdepan, Terluar, dan Tertinggal (Daerah 3T), yang mana menemukan fakta di beberapa Daerah 3T yang masih kekurangan koleksi bahan bacaan dan kelangkaan perpustakaan di kecamatan dan desa. ${ }^{12}$

Mengingat negara memiliki tanggung jawab dalam mencerdaskan kehidupan warga negaranya, maka sudah semestinya negara menyusun suatu bentuk kebijakan pembangunan terkait ketersediaan buku bacaan yang prioritas bagi warga negara di daerah pulau-pulau kecil terluar. Bentuk ini bisa berupa kebijakan pembangunan perangkat lunak (soft ware) maupun kebijakan pembangunan perangkat keras (hard ware) yang mendukung ketersediaan akses buku bacaan bagi warga negara yang berada di daerah pulau-pulau kecil terluar.

Terdapat 111 pulau kecil terluar yang berhadapan langsung dengan negara tetangga yang mana kondisi tersebut sangat rentan konflik, baik dari dalam maupun luar negeri. Isu-isu ketahanan nasional dengan berbagai bentuk konflik horizontal mengancam warga negara di pulau-pulau kecil terluar. Isu anti Pancasila, menguatnya paham terorisme dan radikalisme, isu penyelundupan barang ilegal, perdagangan orang, illegal fishing, soal lingkungan hidup, konflik lahan, SARA, tentu sangat rentan terjadi terhadap masyarakat yang memiliki kondisi dengan pengetahuan wawasan kebangsaan (nasionalisme) yang kurang memadai.

Karakteristik daerah pulau-pulau kecil terluar yang secara posisi dan kondisi akan condong pada urusan "jarak" dan "kebutuhan" distribusi ${ }^{13}$ buku bacaan. Dengan klasifikasi demikian,

12 Sunardi Purwanda. 2020. Hakikat Pemenuhan Hak Atas Buku Bacaan untuk Masyarakat di Daerah Terdepan, Terluar, dan Tertinggal. Disertasi tidak diterbitkan. Makassar: Fakultas Hukum Universitas Hasanuddin, hlm. 204208.

${ }^{13}$ Distribusi umumnya dikenal dalam kegiatan perekonomian atau bisnis, yang menjadi indikator penghubung produsen dan konsumen. Burhanuddin menjelaskan bahwa distribusi dapat diartikan sebagai bentuk penyaluran, baik berupa pembagian atau pengiriman, ke beberapa orang atau ke beberapa tempat; atau dapat juga bermakna persebaran barang dalam suatu wilayah tertentu. Lihat Burhanuddin. 2019. Tanggung Jawab Negara dalam Menjamin Ketersediaan Energi bagi Rakyat. Disertasi tidak diterbitkan. Makassar: Fakultas Hukum Universitas Hasanuddin, hlm. 84. 
negara dapat memenuhkan hak-hak warga negaranya yang berada pada daerah pulau-pulau kecil terluar. Untuk daerah pulau-pulau kecil terluar, secara jarak yang berjauhan dengan wilayah pusat atau pemerintah pusat, berarti masalahnya soal distribusi pengiriman buku bacaan ${ }^{14}$ tidak lepas dari persoalan anggaran. Tanpa distribusi, W. Friedmann menyatakan akan menghadirkan kesenjangan atas standar nilai keadilan yang merupakan sasaran terhadap suatu keadaan khusus atau darurat di masyarakat. ${ }^{15}$

Ongkos kirim buku bacaan bukanlah sesuatu yang murah. Hal mana telah diamini oleh Pemerintah Pusat melalui Kementerian Pendidikan dan Kebudayaan (Kemendikbud) Republik Indonesia. Distribusi sarana pendukung berupa buku pendidikan ke daerah terpencil mengalami kesulitan. Sejauh ini, yang dapat dilakukan oleh Kemendikbud, adalah menyediakan buku-buku dalam jumlah satuan kecil, termasuk ke daerah pulau-pulau kecil terluar secara bertahap. Tahun 2019 Kemdikbud telah mengirim sebanyak 2.402.320 eksemplar buku terdiri atas 60 judul buku, yang dikirim ke 47.678 perpustakaan sekolah berjenjang, 685 taman bacaan masyarakat, dan 40 Perpusda yang ada di daerah-daerah. ${ }^{16}$

Selain itu, ada kebutuhan ${ }^{17}$ bahan bacaan yang sesuai dengan kondisi masyarakat setempat untuk dipenuhkan oleh pemerintah. Tanpa hal itu, masalah kebutuhan buku bacaan akan berdampak pada urusan kualitas pengetahuan dan informasi masyarakat yang berada di daerah pulau-pulau kecil terluar. Jumlah 60 judul buku dari 2.402.320 eksemplar buku yang dibagikan oleh Kemendikbud pada tahun 2019, secara kualitas, masih tergolong rendah. Pemerintah pusat

${ }^{14}$ Tanpa distribusi, industri perbukuan akan gagal memajukan suatu bangsa. Lihat Alfons Taryadi (ed.). 1999. Op.Cit., hlm. 227.

${ }^{15}$ W. Friedmann. 1972. Law in a Changing Society. New York: Columbia University Press, hlm. 45.

16 Lihat di https://www.republika.co.id/berita/pendidikan/eduaction/17/10/27/oyhf2h382-kemendikbud-akuisulit-menghadirkan-buku-ke-daerah-3t

17 Ada lima fungsi hukum menurut Podgorecki, salah satunya adalah fungsi reduksi, yakni hukum berfungsi menyeleksi sikap manusia yang berbeda-beda dalam masyarakat yang kompleks, sehingga sesuai dengan kebutuhan masyarakat. Lihat Dragan Milovanovic. 1988. A Primer in the Sociology of Law. New York: Harrow and Heston, hlm. 121. 
bersama-sama dengan pemerintah daerah setempat mesti menyediakan kebutuhan bacaan masyarakat di daerah pulau-pulau kecil terluar yang berkaitan dengan jenis buku-buku pengetahuan yang berwawasan kebangsaan (nasionalisme).

Pemerintah mesti bekerjasama dengan tokoh-tokoh nasionalis, agamais, budayawan, dalam menciptakan buku yang bertema kebangsaan. Hal ini bertujuan agar konflik-konflik yang berindikasi pada pelemahan nilai-nilai kebangsaan, dapat meminimalisir isu-isu (counter issue) yang dapat memecah belah persatuan bangsa. Selain itu, pemerintah juga mesti memfasilitasi penulis buku anak untuk kebutuhan bacaan anak. ${ }^{18}$ Hal ini bertujuan agar anak-anak Indonesia mendapat asupan bacaan yang lebih banyak, bermutu dan beragam. Di satu sisi, bangsa ini mesti membangun dan mempersiapkan satu generasi literer, dan pada sisi yang lain menciptakan pengalaman berbuku bagi anak-anak di berbagai pelosok negeri ini. Selain memaksimalkan potensi para penulis, potensi penerjemah juga mesti dimaksimalkan. Keterbatasan jumlah judul buku selama ini dapat ditaktisi dengan melakukan proses penerjemahan buku-buku asing ke bahasa Indonesia. Pemerintah harus bersedia membeli hak cipta penulis-penulis dari luar, atau membayar royalti para ahli waris penulis-penulis Indonesia.

Secara kuantitas juga sangat butuh ditingkatkan. Secara kuantitas, perlu memaksimalkan kebutuhan layanan buku bacaan, sebab hal ini tidak dapat dilepaskan dari seberapa banyak jumlah koleksi buku bacaan yang bisa disediakan oleh negara. Mengenai kuantitas buku bacaan ke daerah pulau-pulau kecil terluar, mesti dilakukan secara cermat, sebab jika tidak akan terjadi sesuatu yang timpang, seperti urusan prasarana perpustakaan sekolah/madrasah. Perpustakaan sekolah/madrasah di Indonesia berjumlah 134.718, tetapi jumlah itu tidak melebihi $1 / 4$ dari jumlah sekolah/madrasah yang ada di daerah yang terhitung sekitar 600.000. Belum lagi masih

${ }^{18}$ Dahulu dikenal dengan Proyek Inpres (1973). Lihat tulisan Dwianto Setyawan yang berjudul "Paradigma Buku Bacaan Anak" dalam Frans Magnis Suseno, dkk. 1997. Buku Membangun Kualitas Bangsa. Yogyakarta: Kanisius, hlm. 259-263. 
banyak madrasah/sekolah yang belum memiliki koleksi buku-buku bacaan yang memadai. Penyamarataan jumlah kuantitas buku bacaan ke seluruh perpustakaan madrasah/sekolah akan membuat perpustakaan madrasah/sekolah di daerah pulau-pulau kecil terluar akan tertinggal dari segi kuantitas koleksi. Selain urusan prasarana perpustakaan sekolah/madrasah, pihak pemerintah juga diminta agar tidak memisahkan" "urusan pendidikan" dan "urusan perpustakaan" dengan menyediakan sarana buku bacaan dalam perpustakaan sekolah/madrasah. Sejauh ini, urusan penyediaan buku-buku sekolah/madrasah masih diurus oleh sekolah/madrasah. Pihak sekolah/madrasah lazimnya masih menggunakan dana Bantuan Operasional Sekolah (BOS).

Soal fisik tentu tak lepas dari urusan anggaran keuangan. Penggunaan anggaran terserap banyak pada bagian prasarana, seperti penyediaan bangunan (ruangan) baru dan rehabilitasi bagunan lama. Selain aspek sarana perbukuan dan prasarana perpustakaan, aspek lain seperti sarana pendukung juga butuh dibenahi. Sarana pendukung lainnya seperti mobil perpustakaan yang dimiliki oleh tiap-tiap perpustakaan di daerah-daerah yang dana operasionalnya hanya dapat bertahan sampai tiga bulan, perlu ditingkatkan. Mestinya, dana anggaran untuk operasional kendaraan mesti diperhitungkan kembali, disesuaikan dengan kondisi geografis dan jarak waktu tempuh pada suatu daerah. Hal ini agar desa-desa yang belum memiliki perpustakaan, terbantu dengan hadirnya mobil perpustakaan tersebut. ${ }^{20}$

Pemerintah daerah juga mesti menyediakan sarana pendukung lain, selain mobil pustaka, contohnya dengan menyediakan Perahu Pustaka untuk ke daerah pulau-pulau kecil terluar. Sarana tersebut dapat dijadikan oleh pegiat literasi setempat sebagai kendaraan operasional

${ }^{19}$ Ada pemisahan urusan wajib pelayanan dasar (urusan pendidikan) dan wajib non-pelayanan dasar (urusan perpustakaan) dalam Pasal 12 ayat (1) dan (2) UU No. 23 Tahun 2014 tentang Pemerintahan Daerah, hal ini menyebabkan ketimpangan soal kebutuhan anggaran dari pemerintah. Lihat Sunardi Purwanda. 2020. Op.Cit., hlm, 246-247. Lihat juga https://koranindonesia.id/kemendagri-dorong-penguatan-kelembagaan-perpustakaan-daerah/ ${ }^{20}$ Ibid. 
dalam menyebarkan buku bacaan ke pelosok-pelosok desa, seperti yang dilakukan pegiat literasi di Polewali Mandar, Sulawesi Barat. Selain menjangkau beberapa desa terpencil, Perahu Pustaka di Polewali Mandar juga menyasar pulau-pulau kecil berpenghuni di kawasan Polewali Mandar dan sekitarnya.

Hal lain yang mungkin juga perlu dilakukan, adalah mendorong Dana Desa (DD) untuk menganggarkan prasarana perpustakaan dan sarana buku-buku bacaan untuk masyarakat desa. Dengan alokasi maksimal 10\%, alokasi anggaran untuk bidang lain tentunya tidak akan terganggu. Asalkan dilakukan dengan manajemen, kontrol, dan evaluasi yang baik, serta dilaksanakan secara bertahap dan berkesinambungan. Dari alokasi maksimal $10 \%$ tersebut, taruhlah semisal 100 juta per tahunnya, jika harga buku maksimal Rp. 50.000, maka dalam satu tahun saja, buku sebanyak 2.000 eksemplar sudah menjadi koleksi buku bacaan bagi masyarakat dan pemerintah desa setempat. Dan jika dalam sepuluh tahun saja atau dua periode jabatan kepala desa, pemerintah desa dan masyarakat mungkin mampu mengumpulkan 20.000 eksemplar buku. Sebuah angka fantastis bagi koleksi buku dalam satu perpustakaan desa.

Alternatif lain untuk mentaktisi sulitnya akses dan mahalnya biaya distribusi buku cetak ke daerah pulau-pulau kecil terluar adalah dengan mendorong pemerintah melalui Kemendikbud, Kemendes PDTT dan Kemenkominfo bersama-sama menyediakan jaringan data internet untuk masyarakat di daerah pulau-pulau kecil terluar. Pemerintah menyediakan sebuah situs layanan yang dapat diakses langsung oleh masyarakat daerah pulau-pulau kecil terluar dalam memperoleh pengetahuan dan informasi. Bahan-bahan bacaan tersebut mesti disaring ${ }^{21}$, apakah legal untuk disebarluaskan (lisensi hak cipta, hibah domain publik), apakah kontennya sesuai dengan karakteristik daerah yang dituju, dan mesti ditinjau dan diawasi buku-buku yang mengandung unsur asusila terutama yang terkait dengan buku bacaan anak.

\footnotetext{
${ }^{21}$ Frans Magnis Suseno, dkk. 1997. Op.Cit., hlm. 28.
} 
Tabel 1. Langkah Pemecahan Masalah ${ }^{22}$

\begin{tabular}{ll}
$\begin{array}{c}\text { Bentuk Pemecahan } \\
\text { Masalah }\end{array}$ & $\begin{array}{c}\text { Tanggung Jawab Negara terhadap Pemenuhan Buku Bacaan } \\
\text { untuk Daerah Pulau-pulau Kecil Terluar }\end{array}$ \\
\hline Identifikasi & $\begin{array}{c}\text { Karena berada pada posisi perbatasan dan kondisi masyarakat } \\
\text { yang kurang berkembang, maka ada jarak antara pusat dengan } \\
\text { daerah perbatasan serta kebutuhan buku bacaan yang belum } \\
\text { memadai. }\end{array}$ \\
\hline Diagnosis & $\begin{array}{l}\text { Distribusi Buku dari pusat ke daerah pulau-pulau kecil terluar } \\
\text { kirim buku bacaan ke daerah terluar dan terdepan. Sedangkan }\end{array}$ \\
kebutuhan buku bacaan yang belum memadai di daerah pulau- \\
pulau kecil terluar akan terasa membebani pemerintah dan \\
berdampak pada kualitas pengetahuan dan informasi masyarakat.
\end{tabular}

Dengan adanya buku bacaan, dimungkinkan peradaban akan tetap berlangsung mengisi

kehidupan manusia. Buku ibarat hutan yang luas, sungai yang panjang, gunung yang menjulang, dan laut yang kemilau. Kata-kata dalam buku bacaan adalah rotan yang kuat, mengalir bagai air yang jernih, meneduhkan dengan kerindangannya, namun bisa pula beriak seperti ombak yang sedang marah menghantam karang.

\footnotetext{
${ }^{22}$ Lihat Soetomo. 2013. Masalah Sosial dan Upaya Pemecahannya. Yogyakarta: Pustaka Pelajar, hlm. 28-29. JUSTISI-[2021] UNIVERSITAS MUHAMMADIYAH SORONG 


\section{SIMPULAN}

Untuk mentaktisi soal pemerataan buku-buku bacaan ke daerah pulau-pulau kecil terluar, maka barang tentu tentu yang berjauhan dengan wilayah pusat atau pemerintah pusat, negara dalam hal ini pemerintah wajib mengambil kebijakan pembangunan yang mengedepankan atau memprioritaskan daerah-daerah yang masuk dalam kategori kurang berkembang dan berada jauh dari pusat pemerintahan yang dalam hal ini adalah daerah pulau-pulau kecil terluar. Hal ini semata-mata untuk menciptakan kesetaraan dan memupus kesenjangan pengetahuan yang bakal menumbuhkan kecerdasan segenap warga negara.

\section{DAFTAR PUSTAKA}

\section{Buku}

Alfons Taryadi (ed.). 1999. Buku dalam Indonesia Baru. Jakarta: Yayasan Obor Indonesia dan The Japan Foundation.

Amartya Sen. 1999. Development as Freedom. New York: Alfred A. Knopf.

Burhanuddin. 2019. Tanggung Jawab Negara dalam Menjamin Ketersediaan Energi bagi Rakyat. Disertasi tidak diterbitkan. Makassar: Fakultas Hukum Universitas Hasanuddin.

Dragan Milovanovic. 1988. A Primer in the Sociology of Law. New York: Harrow and Heston. Frans Magnis Suseno, dkk. 1997. Buku Membangun Kualitas Bangsa. Yogyakarta: Kanisius.

Nirwan Ahmad Arsuka. 2008. Semesta Manusia. Yogyakarta: Ombak, hlm. 728 \& 733.

Soetomo. 2013. Masalah Sosial dan Upaya Pemecahannya. Yogyakarta: Pustaka Pelajar, hlm. 28-29.

Sunardi Purwanda. 2020. Hakikat Pemenuhan Hak Atas Buku Bacaan untuk Masyarakat di Daerah Terdepan, Terluar, dan Tertinggal. Disertasi tidak diterbitkan. Makassar: Fakultas Hukum Universitas Hasanuddin.

Triningsih. 2019. Perpustakaan dan Budaya Baca Tulis. Yogyakarta: Azyan Mitra Media. W. Friedmann. 1972. Law in a Changing Society. New York: Columbia University Press.

\section{Website}

https://koranindonesia.id/ https://www.republika.co.id/ 